\title{
Delegation of Powers and the Fiduciary Principle
}

\author{
Giandomenico Majone*
}

\section{Introduction: the analogical fallacy}

No more serious pitfall threatens the student of the European Union than the idea of assessing the EU's institutions and decision processes using the same criteria that are relevant at the national level. For example, in spite of several superficial analogies, one cannot understand the European Parliament using the same conceptual categories which have proved useful in analyzing national parliaments. The EP does not differ from the legislatures of parliamentary democracies only because it lacks their power to tax and spend, to initiate legislation, and to form a government. A more fundamental difference is that the EP is seriously deficient as a representative institution. It cannot represent a (nonexistent) European people in the same sense in which national parliaments represent a historically defined demos, and thus cannot represent, even in theory, a common interest which is more than the sum of the various national interests. Individual interests, on the other hand, are still largely rooted at the national level and hence find their natural expression in national parliaments and political parties All this explains why the real arena of democratic politics continues to be the nation-state, and why European elections are "second order elections": useful perhaps to gauge the popularity of the incumbent national government, but meaningless as an arena where European issues would be debated and settled. It also explains why popular participation in European elections has been constantly decreasing since the first direct elections in 1979, and why the EP does not enjoy sufficient democratic legitimacy to be able, in turn, to legitimate European policies, or other European institutions such as the Commission. The intrinsic limitations of the EP as a representative institution have been recognized by the new Constitutional Treaty, which assigns an explicit role to national parliaments in the process of European integration. Hence, whatever useful part the EP may play in the institutional architecture of the EU, it cannot be evaluated using the same standards we apply to national legislatures.

Similarly, the European Commission is often referred to as "the European executive", but this label is more misleading than useful. Under the Community method, the Commission enjoys the

\footnotetext{
* Paper presented at the CONNEX Workshop, Paris, 11 May 2005
} 
monopoly of legislative and policy initiative. This monopoly has no analogue either in parliamentary or in presidential democracies. In parliamentary systems, legislators introduce relatively few bills; most legislative proposals are instead presented by bureaucrats to the cabinet, which then introduces them as draft legislation to the parliament. Once legislators receive such proposals, however, they are free to change or reject them. This is not the case under the Community method, where as a rule the Council may modify Commission proposals only under the stringent requirement of unanimity. In parliamentary systems, moreover, neither civil servants nor their political masters may preempt the right of initiative of parliamentary parties and of individual members of the legislature. Besides, national executives are the expression of the party or coalition which won the elections, and this is certainly not the case of the European Commission. In a separation-of-powers system like the United States, on the other hand, not only do legislators have the final word over the form and content of bills, but, further, only legislators can introduce bills. In the course of a typical congressional term, members of Congress will introduce several hundred bills on behalf of the president or of executive-branch agencies. During the same period, members of Congress will introduce on their own behalf as many as fifteen thousand or twenty thousand bills (McCubbins and Noble 1995).

It is important to understand clearly what is implied by the Commission's monopoly of legislative initiative. First, other European institutions cannot legislate in the absence of a prior proposal from the "European executive". It is up to the Commission to decide whether the Community should act and, if so, in what legal form, and what content and implementing procedures should be followed. Second, the Commission can amend its proposal at any time while it is under discussion in the Committee of Permanent Representatives of the member states, or in the Council of Ministers, while, as just mentioned, the Council can amend the proposal only by unanimity. If the Council unanimously wishes to adopt a measure which differs from the Commission's proposal, the latter can deprive the main Community legislator of its power of decision by withdrawing its own proposal. Finally, neither the Council nor the EP or a member state can compel the Commission to submit a proposal, except in those few cases where the Treaty imposes an obligation to legislate. In short, the Commission plays a role in the legislative process which is at least as important as its executive role, when it implements the rules which the Council lays down. Again, it should be clear that this institution cannot be understood, much less evaluated, using concepts and standards that are applicable to national executives. Mutatis mutandis, the same is true of the European Central Bank (ECB)—a "body" rather than an institution of the EU in the sense of Article 7 EC. Indeed, there seems to be no historical 
precedent of an independent central bank operating without the political counterweight provided by a full-fledged government.

What has just been said about specific institutions or bodies applies to the EU as a whole, which does not satisfy the democratic criteria it imposes on its member states. Since the late 1980s the continuous growth of European competences, combined with the extension of majority voting in the Council, has given rise to increasingly vocal complaints of a serious 'democratic deficit' in the EU. According to some commentators this democratic deficit is paradoxical -- if the EU were a state it could not be a member of the Union! -- or at least an egregious example of double standards: for example, how can the Union impose on applicant countries conditions which itself is unable to satisfy? In fact, this democratic deficit -- not a total absence but an incomplete development of the practices and institutions of representative democracy -- is not at all paradoxical. Rather, it is the necessary consequence of the lack of popular support for a full-fledged European federal state and, more fundamentally, of the non-existence of a European demos. If a majority of European voters were in favor of a super-state, this would certainly be organized according to democratic criteria--as shown for example by the failed De Gasperi Plan for a European Political Community of the early 1950s, which would have transformed the European Defense Community into an effective federation with a European executive accountable to an elected supranational parliament with powers comparable to those of the national legislatures. Absent popular support for the federal vision, to argue that the Union should be governed democratically because every member state is democratic, is to commit the normative equivalent of the logical fallacy of composition: inferring the property of a whole from a property shared by its component elements. More precisely, the fallacy consists in treating the EU and its member states as if they were members of the same category. A category mistake, according to Gilbert Ryle (1949), consists in discussing certain facts as if they belonged to one logical type or category, when they actually belong to another. Thus it is a category mistake to discuss an institution like a university, in the same terms in which one discusses its departments, professional schools, or administrative offices: the university is not identical with any one of these units; rather, it is the way the units are organized. The pitfall consists in thinking of the university as if it stood for an extra member of the class of which department, schools, and offices are members.

A similar category mistake consists in analyzing the EU by means of the same concepts and criteria we use for its component units -- as if the Union were a state rather than an organization of corporate bodies: the member states and the European institutions (Majone 2005). The principle which Alexander Hamilton considered 'the great and radical vice' of the American Confederation -- namely, 
'the principle of legislation for states or governments in their corporate or collective capacities, and as contradistinguished from the individuals of which they consist' (cited in Rakove 1997: 191, emphasis in the original) -- still prevails at the European level. Judicial doctrines of direct effect and supremacy, and the fact that European law can create rights and duties for citizens of the member states -- rights which can be enforced only by national courts -- do not change this basic fact, which the new Constitutional Treaty has again acknowledged. True, there is also a citizenship of the Union, but only for persons already holding the nationality of a member state. In other words, citizenship is not an autonomous concept of European law, but is defined exclusively by the legislation of the member states.

One of the questions raised by the organizers of this workshop is whether "delegation of powers to a central bank or to an administrative supranational body like the Commission [is] compatible with democracy”. The preceding discussion suggests that this question does not admit any simple, yes or no, answer. Any reasonable conclusion as to what is, or is not, compatible with democracy must carefully distinguish between the national and the European levels. At the European level, as I argue at some length elsewhere (Majone 2005), there is a real trade-off between democracy and integration. Whereas early federalists, at the end of World War II, saw political integration as the necessary condition for bringing democracy back to Europe, it turned out that democracy was able to strike strong roots at the national level, but for lack of popular support could not be transferred to the supranational level, except in a much diluted form. Hence the dilemma between democracy and integration is something that must be kept firmly in mind as we consider the normative dimensions of delegation of powers in the EU. In the final analysis, the democratic deficit is the price we pay for having, in all crucial choices, resolved the dilemma in favor of integration.

\section{Two modes of delegation}

As already mentioned, the Community method is characterized by extensive delegation of legislative and policymaking powers to supranational institutions, in particular to the Commission with its monopoly of agenda setting. Before discussing the normative implications of supranational delegation, let us consider the general question: Why do political principals choose to delegate some of their powers to agents (or fiduciaries) rather than exercising those powers themselves? A number of reasons have been discussed in the literature, ranging from delivering private benefits to favored constituencies, to avoid making unpopular choices. However, the most important reasons for delegating powers, and 
the ones to be considered here are two: first, to reduce decision-making costs, for example by taking advantage of executive branch expertise; and, second, to enhance the credibility of long-term policy commitments.

The logic of delegation varies with the reasons for delegating powers. The main difference between the logic of the two modes just mentioned may be stated as follows. In the former case, where the purpose is to reduce decision-making costs, the key problem facing the political principals is bureaucratic drift, that is, the ability of the agent to enact outcomes different from the policies preferred by those who originally delegated powers. This is the only problem considered by most works on delegation and on the principal-agent model, with which delegation theory is often identified (see, for example, Epstein and O'Halloran 1999). According to this body of literature, the first-best solution of the delegation problem would be for principals to appoint agents who share their preferences. If this is impossible or too costly, then bureaucratic drift should be reduced with the help of various mechanisms of ex ante and ex post control. It is recognized that controls are imperfect, so that there will always remain a difference between the policy enacted and what is implemented, and this residual noncompliance is an important component of agency costs. To calculate the net benefits of delegation, agency costs are to be subtracted from the gains in decision-making efficiency.

The situation is quite different when credibility is the main reason for delegating powers. In this case the best strategy to enhance the credibility of a long-term policy commitment is often to choose a delegate whose policy preferences differ from the preferences of the delegating principal. For example, if a government wants to credibly commit itself to price stability, it can delegate responsibility for monetary policy to a central banker who values ex post inflation less than the government itself, or the median voter. The best-known formalization of this intuitive idea is Rogoff's (1985) model of the 'conservative' central banker. 'Conservative' here means that the banker is more inflation-averse than the government. The government's commitment to a lower average rate of inflation becomes credible precisely because the delegate values ex post inflation less than his political principals. In Rogoff's model the government has a loss function $\mathrm{L}_{\mathrm{G}}$ which depends on deviations of employment, $\mathrm{n}$, and inflation, $\mathrm{p}$, from their socially desired levels $\mathrm{N}$ and $\mathrm{P}$ :

$\mathrm{L}_{\mathrm{G}}=(\mathrm{n}-\mathrm{N})^{2}+\mathrm{g}(\mathrm{p}-\mathrm{P})^{2}$,

where $g$ is the relative weight the government places on inflation stabilization versus employment stabilization. The author proves that the government can improve social welfare by appointing a central banker who is known to value more price stability, relative to unemployment, than the government. The loss function of the conservative banker is: 
$L_{B}=(n-N)^{2}+b(p-P)^{2}$,

where $\mathrm{b}=\mathrm{g}+\mathrm{h}$, with $\mathrm{h}>0$ and possibly quite large.

Thus 'it can be entirely rational for society to structure its central bank in such a way that the monetary authorities have an objective function very different from the social welfare function' (Rogoff 1985: 1186). Intuitively this is because if distortions in the labor market cause the rate of inflation to be too high, then society can be made better off by having the central bank place a higher weight on price stability. It should be noted that Rogoff's model does not explicitly assume that the central bank is independent. Rather, independence is implied by the method of selection: if the central banker is not autonomous in monetary policy decisions, his or her policy preferences are obviously irrelevant. Hence, after the parameter g has been selected by the government, the head of the central bank must be free to implement his/her preferred policy.

Alesina and Grilli (1994) have converted Rogoff's model into an explicit voting model -- where the voters are the member states of the EU -- and applied it to the case of the European Central Bank. In their model, each member state evaluates the consequences of monetary integration according to its own preferences. The authors show that participation in the monetary union can increase national welfare if the preferences of the ECB are more 'conservative' than national preferences. This means that monetary union allows countries to credibly commit themselves to anti-inflationary policies. In fact, popular support for monetary union was strongest in countries with a historically high inflation bias, such as Italy, Spain, and Greece. Apparently, the political leaders of these countries felt that the credibility for price stability, and the resulting reduction in the cost of servicing the public debt, more than compensated for the potential costs in unemployment.

Similar arguments may be used to explain why members of the Commission tend to be more in favor of European integration than the national governments that choose them. Governments may believe that integration of the national economies is the optimal long-run policy, but they also know that they may have short-run incentives to renege on their commitment to respect European rules, such as those disciplining state aid to industry. Choosing as commissioners people who are more prointegration than the government, is a way for the member states to enhance the credibility of their commitment to integration. Again, the logic of the conservative banker model can be extended to such areas of public policy as economic and social regulation. In most countries regulatory policymaking is now delegated to expert agencies operating at arm's length from government. The main purpose of insulating regulators from the political process is to enhance the credibility of long-term policy commitments. Agency heads are chosen not only for their expertise in the relevant area, but also for 
their pro-environment, pro-consumer, or pro-competition beliefs. They generally expect, and are expected by others, to have a well-defined agenda, and to measure their success by the amount of the agenda they accomplish. Regulators also know that courts can review their decisions and may overturn them if they seem to depart too widely from the language and aim of the enabling statute. Hence they have an additional incentive to pursue the statutory objectives of the agency, even when those objectives, because of changed economic or political conditions, no longer enjoy popular support. Thus it is reasonable to assume that the head of an independent agency attaches more importance to the agency's long-term objectives than the government or the majority of voters. In this respect the agency head, like Rogoff's independent central banker, is a fiduciary rather than a mere agent of his or her political principals.

\section{Delegation and political property rights}

An agent who simply carries out the principal's directives cannot enhance the latter's credibility. Hence the second mode of delegation -- the fiduciary mode, as distinct from the agency mode -- implies that the delegate should be independent, although the level of independence will vary with the nature of the task and the seriousness of the credibility problem. Needless to say, the two modes are often combined in practice, as in the case of delegation of powers to the European Commission, see the next section. The difference between these two types of delegation has normative, as well as efficiency, implications. The legitimacy of the principal provides at least prima facie evidence of the legitimacy of the agent's decisions: if the discretion of the agent is suitably controlled, his decisions simply implement the principal's prior decisions. The normative position of an independent delegate is more delicate. In this case, the principal can transfer her powers, but not her legitimacy, to the delegate, hence the latter must find ways of establishing his own legitimacy. To the extent that delegation to a fiduciary involves a net loss of legitimacy, we can speak of fiduciary costs, by analogy with the agency costs of principal-agent theory. While agency costs result from a less than complete control of the agent's behavior, fiduciary costs arise from a poorly defined accountability framework. An example is the limited accountability of the European Commission, both in political and policy terms. As I have shown elsewhere (Majone 2005), such fiduciary costs contribute significantly to the overall democratic deficit of the EU.

The failure to distinguish between the agency and the fiduciary mode of delegation has led to overlook or misinterpret important aspects of EU governance. For instance, agency theory-which 
provides useful insights into the relative effectiveness of various mechanisms to control administrative discretion--has been applied with some success to the study of the 'comitology' system in areas where the Council delegates implementing powers to the Commission. However, the principal-agent model offers no useful insights into the reasons for the treaty-based independence of the Commission in the performance of such functions as agenda setting or monitoring compliance with European law. At best, standard agency theory can explain the independence of the Commission as a failure of the control mechanisms established by the member states, but such a view ignores the fact that this independence is treaty-based.

When speaking of delegation it is important to observe that we are not dealing with a binary variable. Rather, delegation should be thought of as a variable, call it $\mathrm{D}$, ranging more or less continuously over a certain interval, say, between $\mathrm{D}=0$ (no delegation) to $\mathrm{D}=1$ (full delegation). The independence of the delegate increases monotonically with increasing values of D. Murray Horn (1995), who introduced this notation in the context of a formal principal-agent model, does not discuss the limiting case $\mathrm{D}=1$, and hence does not define 'full delegation'. The natural meaning to be assigned to this limiting case is that responsibility in a given area is completely transferred to the delegate. More precisely, what is transferred are political property rights, these being the rights to exercise public authority in a given policy area. In this terminology, the case $\mathrm{D}=1$ corresponds to a complete, and in some cases irrevocable, transfer of certain political property rights -- possibly including some elements of national sovereignty -- to an independent institution.

The notion of political property rights allows us to distinguish more clearly the notion of agency from that of a fiduciary or trustee relation (Majone 2001). The agent is not ordinarily the owner of property for the benefit of the principal. Strictly speaking, when property is transferred to a person who is supposed to manage it for the benefit of a third person, we have not an agency but a special type of fiduciary relation known as trusteeship. In Anglo-American law a trust is a situation where the owner of some property, the 'trustor' (or 'settlor'), transfers it to a 'trustee' with the stipulation that the trustee should not treat it as her own but manage it for the benefit of the 'beneficiary'--who could be the trustor himself. Now, since agency may possess the element of trust and confidence of a fiduciary relation, both agents and trustees can be classed together for many purposes, but the two concepts are distinct. In the legal literature this distinction is sometimes expressed by saying that all trustees are agents but not all agents are trustees: a trustee is an agent and something more (Bogert 1987: 36). The trustee's fiduciary duty is not simply a personal obligation but is attached to a piece of property -- the trust assets. To exemplify, a full delegation of authority over monetary policy may be viewed as a 
transfer of political property rights by the government (the trustor) to an independent central banker (the trustee) for the benefit of the government itself, whose commitment to price stability thereby becomes more credible. In this model the transfer of political property rights is the guarantee of the central bank's independence. The guarantee is particularly strong when the legal basis of the transfer is not a statute, which could be changed by a new parliamentary majority, but a constitutional or quasiconstitutional provision, as in the case of the European Central Bank. Such a transfer is the political analogue of the irrevocable character of most ordinary trusts.

In light of the failure of students of European integration, and of contemporary political science more generally, to appreciate the political significance of fiduciary relations, it may be worthwhile to recall that the notions of fiduciary and political trusteeship play a key role in John Locke's philosophy of government. Locke thought in terms of a contract of society, establishing a political (or “civil”) society, followed by the creation of a fiduciary sovereign under and by a trust-deed. In chapter XIII [149] of the Second Treatise of Government, he writes that the legislative, even though it is the supreme power, is 'only a Fiduciary Power to act for certain ends'. Hence (emphases in the original):

there remains still in the People a Supreme Power to remove or alter the Legislative, when they find the Legislative act contrary to the trust reposed in them. For all Power given with trust for the attaining an end, being limited by that end, whenever that end is manifestly neglected, or opposed, the trust must necessarily be forfeited, and the Power devolve into the hands of those that gave it, who may place it anew where they shall think best for their safety and security.

As Ernest Barker (1962) has pointed out, when Locke speaks of the government as trustee and of the community as both trustor and beneficiary, is not using these terms metaphorically, but as technical concepts derived from the English law of trusts as it existed in his time.

\section{The dual nature of the European Commission}

The conceptual distinctions drawn in the preceding pages allow us to better appreciate the composite nature of the Commission. It is well known that the treaties assign a variety of functions to this institution, but the implications of this variety are not always clearly understood. I have argued that the Commission is not an agent but a fiduciary, or trustee, of the member states when it exercises such treaty-based powers as setting the legislative and policy agenda, ensuring compliance with Community law, or issuing directives and decisions without the Council's approval under Article 86(3) of the EC Treaty. Although the Commission's monopoly of agenda setting has been somewhat eroded in recent 
years, it is still the case that under the Community method the Commission can decide whether the Union should act and, if so, in what legal form, and what content and implementing procedures the proposal should embody. Such extensive powers are hardly compatible with the role of a mere agent.

The situation is quite different when the member states, acting in the Council, determine the conditions under which the Commission is to implement the rules which the Council lays down. The Commission is an agent when it exercises such implementing powers, as shown by the creation of a system of committees of national representatives who are supposed to control the Commission's discretion in the use of its implementing powers -- the so-called 'comitology' system. The ECJ has always upheld the legality of these controls, rejecting the argument that the comitology procedures constitute an unwarranted restriction of the decision-making power of the Commission and jeopardize its independence. Precisely the existence of an extensive system of controls makes it possible to delegate to the Commission extensive executive powers. The Court's reasoning, especially its refusal to see in the comitology system a threat to the Commission's independence, shows that the logic of delegation in the case of implementing powers is different from the other cases mentioned above. Nothing like the comitology system of controls is possible in the case of fiduciary duties. According to Article 213 EC, the members of the Commission must be completely independent in the performance of their duties, neither seeking nor taking instructions from any government or from any other body, and 'each Member State undertakes to respect this principle and not to seek to influence the Members of the Commission in the performance of their tasks'. Reality is, of course, more complicated, but the twofold logic of delegation embedded in the treaty is clear.

\section{Democratic deficit and non-majoritarian institutions}

In the first section of this paper we saw that a "democratic deficit" - in the literal sense of an absence or incomplete development of democratic institutions and processes which are taken for granted at the national level-is inherent in the top-down approach to European integration. Since pro-European sentiment was always an elite phenomenon, no other approach would have worked: hence the democracy/integration tradeoff. Only the transformation of the EU into a full-fledged federal state could resolve this dilemma, but the lack of widespread support for this solution is shown, inter alia, by the fact that nothing like the De Gasperi Plan for a European Political Community — not even the draft Treaty on European Union inspired by the federalist Spinelli Plan and approved by the European Parliament in 1984-has ever been seriously considered by the national governments. However, the 
term "democratic deficit" is not always used in the literal sense. In the literature and in the discourse on European integration the term is also used as a label to denote a set of problems that arise whenever important policymaking powers are delegated to politically independent bodies, such as independent central banks and regulatory authorities. These problems, far from being unique to the EU, are increasingly important at all levels of government as the shift from the interventionist to the regulatory state gains momentum throughout Europe. Democratic deficit, in this second sense, refers to the legitimacy problem of non-majoritarian institutions -- institutions that exercise important public functions but which, by design, are not directly accountable to the voters or to their elected representatives. The growing importance of such institutions in all democratic countries, in spite of persistent doubts about their constitutional status and democratic legitimacy, shows that for many purposes reliance upon qualities such as expertise, professional discretion, policy consistency, fairness, or independence of judgment, is considered to be more important than reliance upon direct democratic accountability. But why is the legitimacy problem of non-majoritarian institutions felt to be more serious at the EU than at the national level? In addition to the general democratic deficit of the Union, which affects all its institutions and decision processes, two more specific reasons seem important. First, the regulatory function is, in relative terms, much more important in the EU than in the member states (Majone 1996). Of the three major functions of modern government in the socioeconomic area -redistribution, macroeconomic stabilization, and regulation -- only the latter falls clearly within the scope of Community competence. Now, the major public actors in regulatory policymaking -regulatory authorities and courts -- are non-majoritarian institutions, hence the legitimacy problems of such institutions loom larger at European than at national level.

The second reason-the apparently unstoppable expansion of Community competences-becomes clear if we compare the main European regulator, the Commission, with the European Central Bank. Also the ECB is a powerful non-majoritarian institution. Its independence, being treaty-based, has a stronger legal foundation than the independence of national central banks--including the old Bundesbank--which usually has only a statutory basis. Not surprisingly, also the 'democratic deficit' of the ECB is becoming a topic of (mostly academic) discussion, but the legitimacy problems of the monetary authority seem to be circumscribed and manageable, more similar to those of the European Court of Justice than to those of the Commission. The legitimacy of a non-majoritarian institution depends, in the final analysis, on its ability to generate and maintain the belief of being, of all feasible institutional arrangements, the most appropriate one for solving a certain range of problems. This concept of a distinctive institutional competence includes the idea of accountability by result, but goes 
beyond it to include a judgment of the quality of the institutional design, the general framework of accountability, and the relation of the institution to the other elements of the governance system. It is clear, for example, that the role of the European Court of Justice could not be played as effectively by any other European institution. But also a body like the ECB can reasonably claim to enjoy a distinctive institutional competence to manage the common currency-given the conditions under which monetary union has been introduced. The Bank's high level of independence is meant to compensate the weakness of macroeconomic governance at European level. For example, some economists have argued that the socially optimal delegation of monetary policy is not to a completely independent central bank. Rather, in order to maximize social welfare, governments should have the option of overriding the central bank's decision under some particular circumstances. Thus, the "optimal" central bank should follow a non-linear decision rule: in the case of small output shocks it determines the acceptable inflation level independently, while in case of large output disturbances, it follows the government's preferences. I have made a similar argument with respect to independent regulatory authorities. In the normal case, such authorities should decide according to their view of what is the most efficient solution of a given regulatory problem. There are, however, cases where the best solution according to the relevant regulatory principles (e.g., competition rules) have broad economic or social implications, and thus imply value tradeoffs which cannot be made by experts, but only by politically accountable leaders. The trick is to make executive interventions in the decision processes of a non-majoritarian institution sufficiently costly in political terms, so that the government is not tempted to interfere except in serious cases. At the national level, this can be achieved by prescribing rigorous and transparent procedures for overriding agency decisions (Majone 1996). A good example is the procedure which the German government must follow if it wishes to override the decision of the Federal Cartel Office in a merger case. In the case of a central bank, another form of delegation is a "performance contract" between the government and the central banker. The terms of the contract can be set to induce the banker to avoid inflation and to stabilize the economy as appropriate. The Central Bank of New Zealand has been cited as an example. At the European level, however, there is no economic government, no generally accepted political counterweight to the central bank, hence it is not clear how performance contracts, or procedures for overriding ECB decisions, could be designed and enforced.

To acknowledge the ECB's distinctive institutional competence is not to overlook the risks entailed by the political decision to move to monetary union. Given this political decision, and the peculiar governance structure of the EU, however, something like the independent ECB was arguably 
the best arrangement that could be devised-a second-best which takes into account the governance deficit as well as the artificial quality of the monetary union. The EU is far from being an optimal currency area, in the sense of being able to make easy domestic adjustments to external shocks. Areas within which factors of production can move readily or are distributed uniformly, can establish a common currency with a reasonable chance of success because balance of payments deficits can be corrected by shifting resources between industries, according to conditions of international demand. In the EU, however, there are no adequate adjustment mechanisms, such as labor flexibility and large budget transfers, to act as effective substitutes for the exchange rate. The EU budget remains very small, with no provisions for a stabilization function, and no indication that the member states are willing to expand it. But a situation where monetary policy is centralized, while fiscal policy is conducted at the national level, may well be unsustainable in the long run. Precisely because of the difficulty of reaching agreement on matters of economic governance, the Maastricht Treaty, although extremely detailed on procedural matters, left a number of fundamental policy questions unanswered. In order to make political agreement possible, the question of measures to coordinate economic policies, or to provide compensatory budgetary transfers, was sidestepped. Also issues of external monetary policy, unitary external representation of the monetary union, exchange rate policy, and political accountability, have been left so far unresolved. In sum, EMU is a high-risk strategy, and there is no easy exit option if things go wrong (Tsoukalis 2000), but all these uncertainties and ambiguities have been carefully concealed from the general public. The chosen strategy simply assumes an irrevocable commitment to the single currency, and accords no place to failure. As the vicissitudes of the Stability and Growth Pact suggest, it may have been a mistake to assign price stability as the sole objective of the central bank, but this was the decision of the member states, not of the ECB's. From the point of view of accountability, though, this explicit, treaty-based commitment has the advantage that the performance of the Bank can be measured unambiguously against the rod provided by the regular statistical measurements of inflation in the Eurozone. In this sense, at least, the ECB is an accountable institution, which is more than can be said about the European Commission.

It is much more difficult to identify the distinctive institutional competence of the Commission. As noted above, most EU policies are regulatory in nature, and in this respect the Commission may be considered a sort of super-agency. However, it has been assigned a variety of other functions: executive, legislative, and quasi-judicial. This multiplicity of functions and objectives expands the scope of the Commission's discretionary choices, thus greatly complicating the task of evaluating the overall quality of the institution's performance. The collegial nature of the institution further 
complicates matters. The European Parliament is understandably reluctant to dismiss the entire college in order to sanction a single commissioner. Moreover, because the Commission has been assigned a large number of separate tasks, it is extremely costly to dismiss it even when there is intense dissatisfaction with how it carries out one such task. As a result, both political accountability and accountability by results are reduced to vanishing point. In the legislative area, for example, 'success' is measured primarily by the number of Commission proposals accepted by the member states, rather than by the quality of the actual results. Moreover, the Commission's control of the legislative and policy agenda, allows it to pursue objectives of political integration and self-aggrandizement while pretending to solve specific policy problems -- integration by stealth. Hence the relative indifference to actual policy outcomes, and the importance attached to process per se.

\section{The accountability deficit}

The organizers of the workshop raised two further questions: whether accountability is a necessary condition for an integration to be successful; and, second, whether central banks should be accountable. My answer to both questions is an unqualified yes. In fact, in the context of European integration the "accountability deficit", rather than the "democratic deficit" should be the main concern. I have already argued that democracy and integration could be made compatible, rather than conflicting, values only if a majority of Europeans supported a federalist outcome of the integration process. Even then it is to be feared that after the first moments of enthusiasm, a European federal state-a United States of Europe satisfying all the criteria of parliamentary democracy--would be unable to attract and retain the loyalty of its citizens. This is because, absent a European demos, the federal government could not legitimately provide many of the public goods (including large-scale income redistribution) which Europeans have come to expect from their government. Unable to compete with the national welfare states, the federation would always be considered a virtual, rather than a real, government, so that the nation-state would remain the real arena of democratic politics (Majone 2005).

When I say that accountability is the real issue, I have in mind not only the lack of effective mechanisms of political responsibility in the EU, but, more generally, our poor understanding of what accountability should mean, and how it may be enforced, at different levels of governance. The theory and practice of accountability, such as they are, are largely based on experience gathered at the national and subnational levels. Hence our ideas in this area are always exposed to the threat of the analogical fallacy discussed at the beginning of the present paper. In order to avoid this pitfall, it is important to 
keep in mind that accountability has many dimensions, of which accountability to the voters or to their elected representatives is only one. In the case of independent central banks and regulatory authorities, in particular, independence may be a necessary, but certainly not a sufficient, condition for accountability. Independence per se may favor excessive and policy discretion, bureaucratic drift, and agency capture. There may even be a tradeoff, at the margin, between independence and accountability. For instance, a multi-headed commission is generally considered to be more independent than a singleheaded agency, but accountability is probably better defined, and easier to enforce, in the case of the agency. Incidentally, this seems to be the reason why Boards, which in the past used to be quite common in Britain (as were Councils elsewhere in old-regime Europe), by mid-nineteenth century were either converted into a formal ministry, or a minister was made directly responsible to Parliament for the activity of the Board. But however important in the historical development of modern ideas of political responsibility, ministerial accountability to Parliament is far from exhausting contemporary notions of accountability. To emphasize this multi-dimensional nature, one should think in terms of accountability vectors, where the different entries denote the various institutions and groups which have a legitimate claim to receive explanations and accounts. Accountability is also a multi-level process, hence the notion of different accountability spaces, corresponding to different levels of governance.

The point of introducing this terminology is to remind us that we cannot reduce accountability to a linear, one-dimensional, process, nor can we expect the same criteria to apply to different levels of governance. At each level of governance - national/sub-national; supranational/regional; international - and along each dimension of accountability, the quality of the accounts given by a non-majoritarian institution depends on the quality of the standards developed by legislators, political executives, the courts, professional opinion and, not least, by the political culture of a given country. In this connection it may be mentioned that central bankers and regulators are often criticized for shortcomings, such as poor accountability, which in many cases are due less to their actions or omissions than to the way the enabling statutes have been written. This suggests that a good accountability framework is to a large extent a matter of good institutional design, reflecting the many dimensions and levels of the accountgiving process. There still is insufficient appreciation of the importance of suitably designed procedures, as unobtrusive and indirect, but powerful, means for enforcing accountability of nonmajoritarian institutions.

In their path-breaking paper on 'Administrative Procedures as Instruments of Control', McCubbins, Noll, and Weingast (1987) use the Administrative Procedure Act (APA), the Freedom of 
Information Act (FOIA), and other US statutes as evidence that procedural rules are not only means of assuring fairness and legitimacy in agency decision-making; they also fulfill important control and accountability functions, providing cost-effective solutions to problems of non-compliance by agencies. In addition to reducing the informational disadvantage of political executives, stakeholders, and citizens at large, procedures can be designed so as to assure that agency decisions will be responsive to the constituents that the policy is supposed to favor. For instance, the procedural requirements under such statutes as the APA and FOIA reduce an expert agency's advantage over its political principals in a number of ways. First, agencies cannot present the political principals with a fait accompli. They must announce their intention to consider an issue well in advance of any decision. Second, the noticeand-comment provisions assure that the agency learns who are the relevant stakeholders, and takes some notice of the distributive impacts associated with various actions. Third, the entire sequence of agency decision-making -- notice, comment, collection of evidence, and construction of a record in favor of a chosen action -- affords numerous opportunities for political principals to respond when the agency seeks to move in a direction that the principals do not approve of. Finally, the broad public participation, which the statutes facilitate, also works as a gauge of political interest and controversy, providing advance warning about serious distributive consequences of the decisions the agency is likely to make, in the absence of political intervention.

Moreover, by controlling the extent and mode of public participation, legislators can strengthen the position of the intended beneficiaries of the bargain struck by the enacting coalition -- the group of legislators that determines the balance of interests represented in the legislation. This has been called 'deck-stacking'. Deck-stacking enables political actors to cause the environment in which an agency operates to mirror the political forces that gave rise to the agency's legislative mandate, long after the enacting coalition has disbanded. The agency may seek to develop a new clientele for its services, but such an activity must be undertaken in full view of the members of the initial coalition, and following procedures that automatically integrate certain interests in agency decision-making. In sum, one important function of procedures is to induce regulatory agencies to take into account broad, politically salient concerns such as environmental quality, or the competitiveness of small and medium-sized firms.

\section{Fiduciary duties and accountability}


The broad discretion and open-ended commitment which characterize fiduciary relationships raise more delicate accountability problems than simple agency. In the case of agency, control and accountability are closely related, even if not synonymous, terms, but this is not true of fiduciary duties. The distinction is important because the fiduciary principle and fiduciary duties play a larger role in EU governance than agency and the normal duties of agents. Thus, under Article $10 \mathrm{EC}$ the member states are responsible for implementing Community law, except when the task has been expressly assigned to a European institution. In this capacity they act as fiduciaries or 'trustees of the common interest' as the Court put it in Case 804/79, Commission v. United Kingdom. As interpreted by the ECJ, Article 10 imposes a reciprocal duty of loyal cooperation between European institutions and national authorities, and between the national authorities themselves. This duty extends beyond specific obligations imposed by particular legal acts: even when there is no specific obligation, a member state's conduct may nonetheless constitute a breach of the fiduciary duty of loyal cooperation (Lenaerts and Van Nuffel 1999). In particular, the jurisprudence of the Court suggests a general duty of the member states to give the Commission any information that may facilitate the fulfillment of the Commission's tasks, even when the Council has not made use of its powers of setting the conditions under which the Commission may collect information or carry out any checks. Symmetrically, the Commission has a duty of loyal cooperation with national administrations and courts, for example in cases involving the application of the Community's competition rules. Again, Article 10 imposes a duty of mutual cooperation between the Commission and the member states whenever the implementation of Community policies runs into unexpected problems.

There are here interesting analogies with corporate law, where the distinction between agency and the fiduciary principle is also important. For example, corporate executives often have an affirmative duty to disclose to other corporate decision-makers information that bears on whether the corporation is about to make a good or bad business decision. As Clark (1985) points out, this duty does not arise from the express terms of the employment contract, but depends on the manager's fiduciary status. Agents usually have relatively fixed obligations under their employment contract. If their contract does not call for a particular performance, they do not have to do it. In contrast, the company executives' 'duty of care' in the exercise of their functions is open-ended, and their duty of loyalty, too, is quite open-ended. As a constraint on directors' pursuit of personal interest, fiduciary duty primarily involves the duty of loyalty. However, in its application to directors' official conduct, fiduciary duty broadens to cover not only selfish actions but also the possibility of negligent behavior (O'Kelley and Thompson 2003). In contrast, in EU governance the duty of loyalty has received much 
greater attention, both in the treaties and in the jurisprudence of the ECJ, than the duty of care. The reason for the emphasis on 'loyalty' rather than 'care' must be sought in the logic of the Community method, for which the question of institutional balance, rather than effective performance, is preeminent (Majone 2005).

The prime theme of the internal political process in the EU is the tug-of-war among independent institutions over the extent and security of their respective jurisdictional prerogatives. The viability of this mode of governance requires that the contest be tempered by a high degree of institutionalization, and by the duty of reciprocal loyalty. On the other hand, since policies are often initiated less to solve concrete problems than to drive forward the integration process, actual outcomes are seldom rigorously evaluated--unless the budgetary costs to the member states become intolerable. This explains why ineffective policies can survive, unexamined and unchallenged, sometimes for decades. For example, it is well known that over its more than twenty year history, the Common Fisheries Policy (CFP) has largely failed in its aim of conserving fishery resources, notwithstanding its seeming institutional advantages over other international fisheries regimes. For reasons I have explained elsewhere (Majone 2005), the objectives of the fisheries conservation policy probably would be better achieved if the policy were re-nationalized, so that each national government could patrol its own Economic Exclusion Zone. Yet, Article I-12 of the new Constitutional Treaty lists "the conservation of marine biological resources under the common fisheries policy” among the exclusive competences of the Union, which has no effective means of monitoring and enforcing conservation regulations.

In addition, the independence of the European institutions means that the traditional mechanisms of political accountability are largely absent. All European treaties emphasize the apolitical character of the Commission, insisting on its complete independence 'from any government or from any other body.' Up to a point, this insulation from the political process makes sense if we think of the Commission as the guardian of the treaties or as an independent regulatory agency. This was indeed what the institution was intended to resemble originally. In the meanwhile, this independent institution has become a highly politicized body, taking decisions involving political judgment and a high level of discretion. In spite of this, the framework of political accountability remains quite weak as already mentioned, the dismissal of the entire Commission is a measure which the European Parliament is understandably very reluctant to use, while there is no possibility of sanctioning an individual Commissioner. At the same time, the limited importance attached to efficiency considerations implies that accountability by results finds limited application under the classical Community method. The parallel drawn above between the European Central Bank and the 
Commission is quite instructive in this respect. While the ECB has a single, clearly defined, and measurable objective -- price stability -- the duties of the Commission not only have greatly expanded over the years, but they have also changed in character. This steady increase in the functions of the Commission has several negative consequences: first, it erodes the narrow legitimacy basis of the institution; second, it makes objective evaluation of actual outcomes practically impossible because of the absence of unambiguous performance standards; finally, the point mentioned above: it is extremely costly for the EP to force the resignation of the Commission in response to even extreme dissatisfaction with the performance of one particular function.

\section{The perils of integration by stealth}

The conservation part of the CFP, although a fairly minor policy sector, illustrates with particular clarity the tension between policy effectiveness and political integration objectives. The problem with the CFP is that it has been shaped more by concerns about Community powers than about effective conservation measures. It has been well said that "the underlying principles of the CFP...have more to do with reinforcing the concept of European unity and cooperation than with effective management of a seriously depleted, highly sensitive and unstable resource. The CFP is a political statement neatly aligned with the Community's general principles, and designed to avoid rocking the European boat” (Symes and Crean 1995). Far from being a minor exception, the case of the CFP is typical of much policymaking under the Community method.

One of the underlying assumptions of this method, as interpreted and applied by the Commission, is the efficacy of the functionalist approach to integration. After the debacle of the European Defense Community in the 1950s, the 'Monnet method' -- the strategy of promoting spillovers from one economic sector to another and eventually from market integration to political integration -- came to be accepted as a more roundabout, but safer, path to the ultimate objective of federal union. Functional spillovers would create pressure for deepening and widening the scope of supranational policymaking, while political spillovers would set in motion a self-reinforcing process of institution-building. Hence the prediction of a steady progress towards federalism. For Monnet's disciples in Brussels the aim of policymaking is less to find the best feasible solution to a concrete problem than to drive forward the integration process: integration by stealth, as it has been called. Hence the indifference to actual policy outcomes and the obfuscation of accountability standards. Also at the national level policy is undertaken, often enough, for political reasons, but there voters can 
express their dissatisfaction at the polls if the gap between policy objectives and actual results is too wide. Since European elections are not fought over European issues, such popular evaluation of the problem-solving capacity of policymakers is simply non-existent in the EU.

Integration by stealth worked, more or less, as long as Community competences were limited, and the emphasis was on negative integration. As the European policy space became increasingly crowded, however, the limits of the approach became evident. After half a century of market building, the idea that economic integration must necessarily lead to a strengthening of the supranational institutions, and eventually to political integration along federalist lines, appears to be increasingly implausible. If one lesson emerges clearly from the history of European integration it is that political objectives should be pursued by overtly political means. Economists have shown that policymaking is more efficient if different instruments are used to achieve different objectives. Applying this prescription to our case leads to the conclusion that objectives of political integration should not be pursued under the guise of technocratic problem solving. By the same token, policies should be designed and implemented to solve concrete problems, not for the sake of political integration. The disjunction of policymaking and political integration would improve the legitimacy of both processes by linking them more directly to the actual (rather than assumed) preferences of the citizens of the Union. It would also facilitate a clearer definition of objectives and the unambiguous assignment of responsibilities, thus reducing the accountability deficit.

What about delegation of powers? As we know, extensive delegation of legislative and policymaking powers to the European institutions - in particular, to the Commission with its monopoly of agenda-setting - is a key characteristic of the Community method. Now, broad delegation of powers presupposes a fiduciary relationship between the delegating authority and the delegate. Integration by stealth amounts to a breach of the fiduciary principle, being an abuse of the powers delegated by the political principals - the member states - only for the purpose of tackling those problems which cannot be solved at the national level. The signs of distrust between the member states and the supranational institutions have been multiplying in recent years. For example, the Maastricht Treaty defined new competences in a way that actually limits the exercise of Community powers by explicitly excluding any harmonization of national law and regulations. Rather than relying on implicit powers, whose limits seemed out of control, the framers of the Treaty on European Union opted for an explicit grant that delimits the mode of action and the reach of such powers (Weiler 1999). A similar approach has been followed by the Amsterdam and Nice Treaties, and also by the new Constitutional Treaty. 
Such care in spelling out the limits of the delegated powers has been taken by a number of commentators to reflect a lack of confidence in the capacity for self-restraint of the supranational institutions. There can be little doubt, Alan Dashwood noted more than two decades ago, that in the 1960s 'harmonization tended to be pursued not so much to resolve concrete problems encountered in the course of constructing the common market as to drive forward the general process of integration. This ... was bound to affect the judgment of the Commission, inclining it towards maximum exercise of the powers available under Article 100 and towards solutions involving a high degree of uniformity between national laws' (Dashwood 1983: 194). The explicit rejection of harmonization in some new areas of Community activity, and the limits on the creation of subsidiary powers not strictly necessary to the functioning of the single market, are clear proof of a growing resistance to the centralizing tendencies of the Commission. In particular, Article 235 of the Rome Treaty (now Article 308 EC) has been used all too often to amend the Treaty without following the normal democratic procedures of ratification and approval by national parliaments. As long as the scope of European law was limited, and trust in the self-restraint of the supranational institutions was maintained, the simplified procedure for adapting the treaty to new conditions had an obvious appeal. Since the Single European Act expanded significantly Community powers, however, the member states have been willing to follow the more complex and politically riskier procedure of formal treaty amendment, rather than delegating to the supranational institutions the task of deciding whether Union action in a given area is needed, and which form it should take. After the SEA, intergovernmental conferences for the purpose of treaty revision have taken place every few years. Treaty amendment has become almost a routine procedure, initiated as soon as a new treaty has been accepted by the national governments. The Constitutional Treaty, even if ratified by all the member states, is unlikely to be the end of the process.

\section{Conclusion: the EU between delegation and self-government}

As social-contract theorists well knew, delegation of powers is not the only mechanism by which a community of free people (or of sovereign states) can solve collective-action problems. A community, once formed by a contract of society, can operate according to different principles. It may be selfgoverning, without any distinction of ruler and subjects. This was the theory of Rousseau, who excluded categorically any delegation of sovereign (i.e., legislative) powers, while allowing delegation of executive powers, but only temporarily and subject to limitations or repeal at the community's pleasure. Again, the community may appoint a fiduciary or trustee government, which it can dismiss 
for breach of trust on its own interpretation of the nature of the trust: Locke's theory. There is a third possibility: the community may transfer every right and every power which it possesses to a sovereign Leviathan: the theory of Hobbes. Thus, whereas Rousseau sets very strict limits to the powers which a community may delegate, and Hobbes assumes that the members of the community transfer all their powers to the government, Locke understands that powers may be delegated piecemeal. For him, even the legislative power is only a fiduciary power to act for certain ends, and the members of the community retain the capacity to remove the legislators, or limit the scope of their powers, if they acted contrary to the trust placed in them. In the preceding section, for example, we saw instances where the community of the member states of the EU revoked or limited some of the powers previously delegated to the supranational institutions.

These observations are meant to suggest that certain strands of social-contract theory can provide useful perspectives on the different configurations of European governance. We can of course exclude the Hobbesian strand, since no member state is prepared to surrender the core of national sovereignty and transfer all its rights and powers to a super-state. In contrast, both Rousseau and Locke offer different but complementary perspectives on the nature of European governance. Rousseau's idea of a self-governing community is particularly relevant to policy fields like foreign affairs and security policy, where the member states act outside the framework of the Community method. In areas close to the core of national sovereignty Rousseauean self-government provides a better model, both normatively and descriptively, than Lockean delegation of powers to the supranational institutions. In the literature on European integration, self-government by the community of member states is usually called intergovernmentalism, but this label does not really capture the character of EU governance today. As Helen Wallace points out, 'intergovernmentalism' resonates too much of cooperation between governments in international organizations whose role is limited to providing secretariat services and a forum for debate. She suggests a different term, 'intensive transgovernmentalism', to connote those situations where the member states have been prepared to commit themselves to rather extensive engagement and disciplines, but have judged the Community method to be inappropriate or unacceptable. The main institutional characteristics of this mode of non-Community policymaking are: the active role of the European Council in setting the overall direction of policy; the predominance of the Council of Ministers in consolidating cooperation; the limited or marginal role of the Commission; and the virtual exclusion of the EP and ECJ from the policy process, together with extensive reliance on networks of national policymakers (Wallace 2000: 33-4). “Confederal arrangements” is an older but perhaps clearer characterization of this mode of governance. The advantage of the older terminology is 
that it leads one to conclude that the EU is a failed federation, but a successful prototype of postmodern confederation (Majone 2005).

Be that as it may, it is clear that no single mode, however powerful, of transnational cooperation can match the complexity of European governance. The real problem facing the member states today is not to choose between 'self-government' and delegation to supranational institutions, but how to combine the two approaches optimally. The advantages and limitations of confederal arrangements -broadly understood to include the various 'new governance' methods -- are in a sense the reverse of those of the Community method. Flexible, respectful of national autonomy, and sustained by the legitimacy of democratically elected leaders, such arrangements can achieve results that are precluded to the supranational approach. On the other hand, the price of operating free of the constraints of the Community method may be the loss of legal certainty and the opaqueness of the process. These differences -- which are partly explained by the differences in the policy areas to which the two methods are applied -- suggest a useful complementarity, rather than mutual exclusiveness. Embedded in an information-rich environment (which facilitates coordination by mutual adjustment) and supported by suitable strategies of credible commitment, confederal arrangements will be an increasingly viable and effective method for driving forward the process of European integration in certain politically sensitive areas. The available empirical evidence, when carefully examined, does not support any a priori reason why 'self-government' by the member states cannot work, or why it should be only a second-best alternative to the Community method. On the contrary, the evidence suggests that centralized coordination and a greater role of the Commission are not adequate responses to such problems as those of monetary union or foreign and security policy, which have other sources.

On the other hand, the single European market still needs the legal certainty which the Community method, with its binding rules and independent supranational institutions, can provide. But legal certainty is better ensured by 'negative' law -- preventing the member states, and the European institutions themselves, from engaging in discretionary behavior -- than by measures of positive integration, which often produce unpredictable or sub-optimal outcomes. The situation in Europe has changed radically since the late 1950s. A reform of the Community method is certainly needed, but not along the lines indicated in the White Book on European Governance and in subsequent documents by the Brussels authorities, which would extend this method to all Union policies, and transform the Commission into a full-fledged 'government of Europe'. The truth is that the Community method is too rigid to be easily adapted to new situations and new tasks, while its narrow legitimacy basis rules out its expansion beyond the limits of economic integration. For these reasons, restricting the scope of the 
Community method can only enhance its legitimacy, while its generalization would weaken, perhaps fatally, the process of European integration. The challenge facing students of European integration today is to investigate methods - other than delegation to supranational institutions - by which member states can credibly commit themselves to collective action.

\section{References}

Alesina, A. and Grilli, V. (1994). 'The European Central Bank: Reshaping Monetary Politics in Europe', in T. Persson and G. Tabellini (eds.), Monetary and Fiscal Policy, Vol. 1. Cambridge, MA.: The MIT Press, 247-78.

Barker, E. (1962). 'Introduction’, in E. Barker (ed.) Social Contract: Locke Hume Rousseau. New York: Oxford University Press, vii-xliv.

Bogert, G. T. (1987). Trusts (6th edn). St. Paul, MINN.: West Publishing Company.

Clark, R. C. (1985). ‘Agency Costs Versus Fiduciary Duties’, in J. W. Pratt and R. J. Zeckhauser (eds.) Principals and Agents: The Structure of Business. Boston, MA.: Harvard Business School Press, 55-79. Dashwood, A. (1983). ‘Hastening Slowly: The Communities' Path towards Harmonization', in H. Wallace, W. Wallace, and C. Webb (eds.), Policy-Making in the European Community (2nd edn). Chichester: Wiley, 177-208.

Epstein, D. and O'Halloran, S. (1999). Delegating Powers. Cambridge: Cambridge University Press. Horn, M. J. (1995). The Political Economy of Public Administration. Cambridge: Cambridge University Press.

Lenaerts, K. and Van Nuffel P. (1999). Constitutional Law of the European Union. London: Sweet and Maxwell.

McCubbins, M. D. and Noble, G. W. (1995). 'The appearance of power: legislators, bureaucrats, and the budget process in the United States and Japan', in P. F. Cowhey and M. D. McCubbins (eds.), Structure and Policy in Japan and the United States. New York: Cambridge University Press, 56-80. — Noll, R.G., and Weingast, B.R. (1987). 'Administrative Procedures as Instruments of Political Control'. Journal of Law, Economics, and Organization, Vol. 3: 243-77.

Majone, G. (1996). Regulating Europe. London: Routledge.

— (2001). 'Two Logics of Delegation: Agency and fiduciary relations in EU governance'. European Union Politics, 2/1: 103-22. 
— (2005) Dilemmas of European Integration: The Ambiguities and Pitfalls of Integration by Stealth. Oxford: Oxford University Press.

O’Kelley, C. R. T. and Thompson, R. B. (2003). Corporations and other Business Associations (4th edn). New York: Aspen Publishers.

Rakove, J. N. (1997). Original Meanings. New York: Vintage Books.

Rogoff, K. (1985). 'The Optimal Degree of Commitment to an Intermediate Monetary Target'. Quarterly Journal of Economics, 100: 1169-90.

Ryle, G. (1949). The Concept of Mind. New York: Barnes \& Noble Books.

Tsoukalis, L. (2000). 'Economic and Monetary Union', in H. Wallace and W. Wallace (eds.), PolicyMaking in the European Union (4th edn). Oxford: Oxford University Press, 149-78.

Wallace, H (2000). 'The Institutional Setting', in H. Wallace and W. Wallace (eds.), Policy-Making in the European Union (4th edn). Oxford: Oxford University Press, 3-37.

Weiler, J. H. H. (1999). The Constitution of Europe. Cambridge: Cambridge University Press. 